\title{
FASILITAS BELAJAR SEBAGAI FAKTOR YANG MEMPENGARUHI HASIL BELAJAR IPA KELAS IV SD
}

\begin{abstract}
Abstrak
Penelitian yang dilakukan ini bertujuan untuk menganalisis pengaruh fasilitas dan hasil belajar IPA kelas IV SD. Penelitian yang digunakan adalah peneltian kualitatif dimana objek yang di teliti berupa hasil dari suatu proses pembelajaran. Penelitian kualitatif merupakan penelitian yang dilakukan pada kondisi alamiah, yang berkembang apa adanya, tidak dimanipulasi oleh peneliti. Penelitian kualitatif pada umumnya dilakukan dalam konteks penelitian evaluasi atau survey. Peneliti melakukan penelitian melalui observasi di beberapa sekolah dasar di kota Salatiga dengan pengaruh fasilitas yang digunakan saat proses pembelajaran, Analisis yang dilakukan menggunakan analisis deskriptif. Hasil penelitian yang didapat terhadap beberapa sekolah dasar yang telah dilakukan survey menggenai fasilitas dan hasil belajar siswa yakni SD Negeri Salatiga 05 dengan jumlah siswa 33 orang, SD Negeri Ledok 06 dengan jumlah siswa 14 orang, dan SD Kanisius Gendongan Salatiga dengan jumlah siswa 39 orang. Selain itu terdapat nilai rata-rata dari setiap sekolah dasar sebagai berikut: SD Negeri Salatiga 05 dengan nilai rata 71, SD Negeri Ledok 06 dengan nilai rata-rata yakni 60. Sedangkan SD Kanisius Gendongan Salatiga dengan jumlah nilai rata-rata siswa yakni 75.
\end{abstract}

Kata Kunci: Fasilitas belajar, hasil belajar IPA.

\begin{abstract}
The research conducted aims to analyze the influence of facilities and learning outcomes of fourth grade natural science. The research used is qualitative research where the object being examined is the result of a learning process. Qualitative research is research conducted on natural conditions, which develop as they are, not manipulated by researchers. Qualitative research is generally carried out in the context of evaluation or survey research. The researcher conducted research through observations in several elementary schools in Salatiga with the influence of facilities used during the learning process, The analysis carried out using descriptive analysis. The results of the research obtained on several elementary schools that have been surveyed regarding the facilities and learning outcomes of students namely SD Negeri Salatiga 05 with 33 students, Ledok 06 Elementary School with 14 students, and Kanisius Gendongan Elementary School Salatiga with 39 students. In addition there is an average value of each elementary school as follows: SD Negeri Salatiga 05 with an average value of 71, SD Negeri Ledok 06 with an average value of 60. While SD Kanisius Gendongan Salatiga with an average value of 75 students..
\end{abstract}

Keywords: Learning facilities, science learning outcomes.

\footnotetext{
${ }^{1}$ Pendidikan Guru Sekolah Dasar, Fakultas Keguruan dan Ilmu Pendidikan, Universitas Kristen Satya Wacana

Alamat email 292016151@student.uksw.edu
} 


\section{PENDAHULUAN}

Fasilitas merupakan faktor yang memiliki peran penting dalam situasi pembelajaran di sekolah. Keberhasilan proses belajar mengajar dapat dilihat dari hasil capaian siswa. Pada dasarnya ada faktor yang bisa mempengaruhi keberhasilan dalam pendidikan salah satunya, seperti, sarana dan prasarana (fasilitas), guru, siswa, lingkungan pendidikan, dan kurikulum. Dari beberapa faktor di atas fasilitas (prasarana) belajar siswa di sekolah memiliki andil yang cukup besar. Fasilitas belajar siswa yaitu alat-alat yang digunakan dalam rangka memudahkan pembelajaran dan menunjang kegiatan pembelajaran. Fasilitas belajar yang cukup mampu memenuhi kebutuhan pada proses belajar mengajar bisa mendukung siswa dalam mencapai hasil belajar yang optimal dan prestasi yang bagus. Hal ini sesuai dengan pendapat yang dikemukakan oleh Aunurrahman (2011) menyatakan bahwa prasarana dan sarana pembelajaran merupakan faktor yang bisa memberikan pengaruh terhadap hasil belajar siswa. Tercukupinya fasilitas belajar dapat memperlancar proses belajar siswa agar bisa mencapai hasil belajar yang maksimal. Jadi hasil belajar siswa akan lebih baik jika didalam kegiatan belajar mengajar didukung oleh alat-alat pelajaran yang relevan dan komplit.

Lawanson (2011:47-48) menyatakan bahwa fasilitas belajar bisa dikatakan sebagai suatu hal yang memungkinkan guru untuk melakukan pekerjaannya dengan sangat baik dan bisa membantu siswa untuk belajar secara efektif. Fasilitas terdiri dari sarana dan prasarana belajar. Sanjaya (2010:18) mengemukakan sarana belajar adalah segala sesuatu yang membantu mendukung terhadap kelancaran proses pembelajaran di sekolah. Sedangkan prasarana adalah alat yang tidak langsung yang membantu dalam mencapai tujuan pendidikan, misalnya ruang, buku, perpustakaan, laboraturium dan sebagainya. Sarana Pendidikan dibedakan menjadi tiga macam jika ditinjau dari hubungannya dengan proses belajar mengajar, misalnya buku, alat peraga, alat tulis dan media pengajaran (Daryanto dan Farid 2013) bahwa yang paling terlibat dalam perencanaan sekolah dan untuk meningkatkan hasil belajar dengan menciptakan lingkungan yang lebih baik. Fasilitas merupakan suatu yang sangat penting sebagai proses pembelajaran dan juga bisa menimbulkan minat dan perhatian peserta didik untuk mempermudah penyampaian materi. Kegiatan pembelajaran di kelas membutuhkan fasilitas agar proses belajar dapat berjalan dengan lancar dan teratur. Fasilitas yang termasuk dalam kegiatan belajar mengajar di sekolah antara lain seperti ruang kelas,ruang perpustakaan, laboratorium dan media pengajaran. Namun pada dasarnya fasilitas yang mendukung kegiatan belajar mengajar belum terlalu dimanfaatkan secara optimal oleh para pendidik dalam kegiatan pembelajaran di sekolah.

Selain itu salah satu muatan yang dapat menggunakan sarana dan prasarana (fasilitas) adalah muatan IPA. Mata pelajaran IPA pada dasarnya merupakan suatu produk dan proses. Produk IPA yang dimaksud yaitu meliputi fakta, konsep, prinsip, teori dan hukum. Sedangkan proses IPA meliputi cara-cara memperoleh, mengembangkan dan penerapan pengetahuan yang mencakup cara berpikir, cara kerja cara menyelesaikan masalah, dan cara bersikap. Oleh karena itu, IPA dirumuskan secara sistematis, terutama atas dasar pengamatan eksperimen. IPA merupakan ilmu pengetahuan tentang alam atau ilmu yang di dalamnya mempelajari peristiwa yang terjadi di alam (Samatowa, 2010: 3).

Berdasarkan observasi langsung dilapangan proses pembelajaran IPA selama ini justru sering dilakukan dengan cuma memberikan ceramah atau saat pembelajaran pendekatan yang digunakan guru dalam pembelajaran masih bersifat konvensional. Pendekatan seperti ini menurut saya masih kurang sesuai dengan kebutuhan siswa maupun tuntutan dalam kurikulum. Pembelajaran yang masih berpusat pada guru cuma hanya melatih siswa ketika hanya menyelesaikan permasalahan soal-soal di dalam buku. Aktivitas siswa dalam proses pembelajaran sangat minim dengan kata lain siswa hanya pasif menerima informasi dan menunggu perintah guru. Siswa jarang diberikan pembelajaran langsung menggunakan media 
atau alat untuk belajar seperti pada pembelajaran IPA menggunakan KIT IPA, praktek di LAP dan media IPA lainnya seperti kerangka manusia. Permasalahannya yang terjadi saat ini adalah masih sangat kurang pemanfaatan alat-alat IPA seperti KIT, dan alat praktek lainnya pada setiap proses belajar mengajar. Hal ini dikarenakan masih terdapat di beberpa sekolah masih menggunakan kurikulum yang berbeda seperti KTSP dan untuk kurikulum 2013 belum semuanya merata di setiap sekolah. Hal seperti ini membuat kualitas pembelajaran menjadi menurun dan kurang memuaskan karena dalam sistem pembelajaran masih ada perbedaan dalam penggunaan kurikulm. Tujuan dilakukan sebuah penelitian ini yaitu untuk membantu meningkatkan hasil belajar siswa pada mata pelajaran IPA dengan pengunaan fasilitas seperti KIT, dan alat lainnya, Pada proses meningkatkan hasil belajar siswa digunakan suatu penerapan Pendekatan Sains Teknologi Masyarakat (STM). Sain Teknologi Masyarakat (STM) merupakan suatu usaha untuk menyajikan Ilmu Pengetahuan Alam dengan masalah-masalah dari dunia nyata. Widyaningtias (2009:99-106), menyatakan bahwa pendekatan Sains Teknologi Masyarakat dapat langsung menghubungkan kehidupan dunia nyata anak sebagai anggota masyarakat dengan kelas sebagai ruang belajar IPA. Proses pendekatan ini dapat memberikan pengalaman belajar bagi siswa dalam mengidentifikasi potensi masalah, mengumpulkan data yang berkaitan dengan masalah, mempertimbangkan solusi alternatif dan mempertimbangkan konsekuensi berdasarkan keputusan tertentu. Pembelajaran IPA dalam konteks Sains Teknologi Masyarakat diharapkan siswa dapat berpikir tentang cara mengaitkan konsep sains dengan teknologi, masyarakat dan dampaknya bagi lingkungan serta isu-isu sosial (Trisnayanti, 2010: 61-72).

Jadi hasil belajar dapat kita lihat dari proses pembelajaran yang dilaksanakan di kelas. Hasil belajar merupakan suatu penilaian diri peserta didik. Proits dalam (Molstad \& Karseth, 2016) mengungkapkan bahwa hasil belajar dapat menggambarkan kemampuan peserta didik dari apa yang mereka ketahui dan pelajari. Hasil belajar peserta didik dapat dikatakan sebagai pernyataan atas apa yang peserta didik ingin ketahui, mengerti atas apa yang disampaikan atau bahkan yang ingin diperoleh dari kesuksesan penyelesaian pembelajaran mereka menurut Gudeva, Dimova, Daskalovska, \& Trajkova, 2012. Hasil belajar yang mereka peroleh dapat dijadikan tolak ukur dalam mengidentifikasi dan mengevaluasi cita-cita pendidikan (Aziz, Yusof, \& Yatim, 2012:1306-1311). Hasil belajar mengacu kepada pengetahuan yang diperoleh sebagai hasil dari kegiatan pembelajaran. Jadi yang harus kita ketahui bahwa fasilitas merupakan suatu alat pendukung dalam proses pembelajaran di sekolah. Sehinga fasilitas yang ada di sekolah sebaiknya di manfaatkan secara efesien agar dalam prosesnya bisa membantu meningkatkan mutu pembelajaran dan menghasilkan nilai yang bagus dan memuaskan pada siswa kelas IV SD. Namun pada kenyataannya bahwa masih minim penggunaan fasilitas belajar di beberapa sekolah dasar yang mengakibatkan nilai siswa sedikit kurang. Ada beberapa faktor yang mempengaruhi hasil belajar yaitu: faktor eksternal dan faktor internal. Faktor eksternal meliputi: a) faktor lingkungan sosial b) faktor lingkungan nonsosial. Faktor utama yang mempengaruhi hasil belajar siswa antara lain: 1) Faktor internal.

Berdasarkan latar belakang masalah diatas, dapat kita rumuskan permasalahan dalam penelitian ini adalah bagaimana meningkatkan hasil belajar siswa pada mata pelajaran IPA kelas IV di beberapa SD di Salatiga dengan penerapan pendekatan Sains Teknologi Masyarakat. Tujuan yang ingin dicapai untuk penelitian ini yaitu untuk mengetahui peningkatan hasil belajar siswa kelas IV di beberapa SD yang sudah dilakukan penelitian dengan penerapan pendekatan Sains Teknologi Masyarakat pada mata pelajaran IPA. Adapun penelitian ini adalah sebagai bahan masukan bagi guru tentang suatu pembelajaran alternatif untuk memperbaiki kualitas pembelajaran yaitu dengan memanfaatkan fasilitas untuk menunjang suatu pembelajaran yang lebih merarik dan mudah di serap siswa. Dengan hal ini bisa memberikan pengalaman langsung kepada siswa mengenai kebebasan belajar secara aktif dan kreatif sesuai dengan perkembangan berpikirnya. 


\section{METODE}

Penelitian yang dilakukakan ini menggunakan teknik observasi dan survey. Dimana teknik ini dianggap tepat karena penelitian yang dilakukan ini untuk mengumpulkan informasi faktual melalui observasi langsung. Teknik observasi, dilakukan selama kegiatan pembelajaran di sekolah. Subyek yang diteliti yaitu siswa kelas IV sekolah dasar yang ada di sekitar kota Salatiga. Observasi yang dilakukan terdapat di beberapa tempat sekolah seperti di SD Negeri 05 Salatiga, SD Negeri Ledok 06, dan SD Kanisius Gendongan Salatiga. Terdapat ada tiga sekolah dasar yang dilakukan observasi yaitu, SDN Ledok 06 dengan jumlah siswa 14 orang, SDN 05 Salatiga dengan jumlah siswa 33 orang, dan SD Kanisius Gendongan Salatiga dengan jumlah siswanya 39 orang.

Teknik yang digunakan selain ovservasi dan survey yaitu teknik analisis deskriptif. Analisis deskriptif adalah suatu metode penelitian yang ditujukan untuk menggambarkan fenomena-fenomena yang ada, yang berlangsung pada saat ini atau saat yang lampau. Menurut Sugiyono (2013:53), mendefinisi analisis deskriptif adalah sebagai suatu rumusan masalah yang berkenaan dengan pertanyaan terhadap keberadaan variabel mandiri, baik hanya pada satu variabel atau lebih (variabel mandiri adalah variabel yang berdiri sendiri, bukan variabel independen, karena kalau variabel independen selalu dipasangkan dengan variabel dependen).

Penelitian yang digunakan adalah peneltian kualitatif dimana objek yang di teliti berupa sebuah hasil dari suatu proses pembelajaran. Penelitian kualitatif merupakan penelitian yang dilakukan pada kondisi alamiah, yang berkembang apa adanya, tidak dimanipulasi oleh peneliti. Penelitian kualitatif pada umumnya dilakukan dalam konteks penelitian evaluasi atau survey.

Penelitian tentang fasilitas belajar adalah factor yang mempengaruhi hasil belajar siswa kelas IV SD. Fasilitas belajar (variabel X), yaitu alat-alat yang digunakan dalam rangka memudahkan dalam proses pembelajaran dan menunjang kegiatang pemebelajaran. Hasil belajar siswa (variabel Y), yaitu suatu pencapaian yang di dapat melalui proses belajar mengajar selama waktu yang telah ditentukan. Hasil belajar merupakan kemampuan yang siswa ketahui dan pelajari. Penelitian ini selain menggunakan teknik observasi juga menggunakan pendekatan yaitu Sain Teknologi Masyarakat (STM). Dengan pendekatan ini diharapkan bisa membantu siswa dalam proses belajar di kelas. Pendekatan ini bisa mengajarkan siswa berpikir bagaimana cara mengaitkan konsep sain dengan teknologi.

Selain melalui survey juga menggunakan pengumpulan data dimana harus melalui tiga cara, yaitu: dengan Tes hasil belajar siswa untuk mengetahui peningkatan hasil belajar IPA. Teknik observasi dan survey, dilakukan selama kegiatan pembelajaran berlangsung. Sesuai dengan apa yang telah disiapkan oleh peneliti dengan maksud agar mengetahui fasilitas yang ada di sekolah dan hasil belajar IPA SD kelas IV. Kegiatan pembelajaran yang berlangsung untuk mengetahui kegunaan fasilitas yang ada dengan menjadi sebuah media pembelajaran contohnya seperti KIT IPA. Sesuai pendahuluan dan tinjauan pustaka tujuan penelitian ini untuk mengetahui pengaruh fasilitas belajar terhadap hasil belajar IPA kelas IV SD.

\section{HASIL DAN PEMBAHASAN}

Kegiatan survey dilakukan untuk mengetahui keadaan nyata yang ada di lapangan. Dari hasil survey fasilitas belajar pada beberapa Sekolah Dasar di Salatiga menunjukkan secara umum fasilitas belajar belum begitu efektif digunakan. Dari beberapa sekolahan yang sudah dilakukan observasi langsung terdapat beberapa fasilitas yang ada yang dan sering digunakan 
bahkan ada yang jarang digunakan pada saat pembelajaran berlangsung. Penggunaan fasilitas atau bahan ajar lain sangat mempengaruhi pada hasil belajar. Karena fasilitas salah satu sebagai manfaat untuk membantu siswa agar mudah dan cepat mengerti ketika pembelajaran berlangsung. Tujuannya agar ketika dalam proses pembelajaran berlangsung lebih mudah di pahami dan siswa lebih cepat tanggap dengan bantuan menggunakan media yang ada. Diharapkan fasilitas IPA di sekolahan bisa digunakan sebaik-baiknya untuk membantu kelancaran dan memudahkan siswa dalam memahami pembelajaran.

Sementara fasilitas yang ada di setiap sekolahan pada umumunya terdapat fasilitas seperti KIT IPA, dan alat praktek lainnya. Beberapa sekolah dasar ini fasilitas yang tersedia kebanyakan hanya KIT IPA saja dan media lainya seperti kerangka manusia. Di SD yang sudah dilakukan survey hampir semua tidak memiliki ruang Laboratorium IPA sendiri. KIT IPA yang dimaksud adalah kit listrik (baterai, bola lampu, saklar), kit sederhana (katrol, neraca), kit magnet (magnet batang, magnet tabung). KIT yang seperti ini kebanyak biasanya setiap sekolah dasar sudah memilikinya.

Hasil survey beberapa sekolah dasar di kota Salatiga terdapat hasil nilai rata-rata IPA siswa kelas IV SD di kota Salatiga. Hasil analisis prestasi belajar IPA dalam penelitian ini diterangkan bahwa ada beberapa SD dimana nilai rata-rata IPA Kelas IV berpengaruh pada fasilitas yang ada di sekolah. Berikut adalah klasifikasi dari beberapa sekolah dasar yang sudah dilakukan penelitian:

\section{Tabel 1.}

\begin{tabular}{|c|c|c|c|}
\hline No & Nama Sekolah & Jumlah Siswa & Nilai Rata-rata \\
\hline 1. & SD Negeri Salatiga 05 & 33 orang & 71 \\
\hline 2. & SD Negeri Ledok 06 & 14 orang & 60 \\
\hline 3. & $\begin{array}{c}\text { SD Kanisius } \\
\text { Gendongan Salatiga }\end{array}$ & 39 orang & 75 \\
\hline
\end{tabular}

Berdasarkan hasil ketiga tabel diatas dapat kita simpulkan bahwa nilai rata-rata IPA kelas IV dari beberapa sekolah dasar di kota Salatiga sebagai berikut SD Kanisius Gendongan Salatiga nilai rata-rata siswanya yaitu 75. SD Negeri Ledok 06 nilai rata-rata siswa kelas IV yaitu 60. Sedangkan nilai rata-rata IPA kelas IV SD Negeri Salatiga 05 yaitu 71 . Hal ini menjadi salah satu alasan kenapa nilai rata-rata siswa kelas IV SD Negeri Ledok 06 masih kurang dari dua sekolah dasar yang lainnya. Dari ketiga SD yang ada di Salatiga ini yang sudah dilakukan survey terdapat salah satunya SD yang penggunaan fasilitas atau media lainnya sangat kurang ketika dalam pembelajaran yaitu SD Negeri Ledok 06. Sedangkan di dua SD lainya masih sering dalam penggunaan fasilitas seperti KIT IPA dan media kerangka manusia. Maka dapat kita simpulkan bahwa fasilitas belajar sangat dibutuhkan pada saat proses pembelajaran guna membantu agar mudah di mengerti dan di pahami siswa.

\section{Ucapan Teria Kasih}

Demikian terselesainya artikel ini penulis mengucapkan terimakasih kepada semua pihak yang membantu. Penulis juga menyadari bahwa dalam penulisan artikel ini juga masih ada kekurangan, sehinga penulis sangat mengharapkan saran dan tanggapan dari pembaca. 


\section{SIMPULAN}

Kesimpulan dari hasil penelitian, yakni terjadi penurunan hasil belajar siswa Kelas IV SD Negeri Ledok 06 pada mata pelajaran IPA dikarenakan penggunaan fasilitas yang ada sangat kurang dalam menunjang pembelajaran. Sementara tuntutan dalam dunia pendidikan bahwa pembelajaran yang kreatif harus menggunakan media atau alat yang ada seperti KIT IPA, dan contoh lain seperti media kerangka manusia. Peningkatan hasil belajar IPA dari nilai rata-rata untuk beberapa SD seperti SD Kanisiun Gendongan Salatiga 75 dengan jumlah siswa 39 orang. SD Negeri Ledok 06 nilai rata-rata 60 dengan jumlah siswa 14 orang. Sedangkan SD Negeri Salatiga 05 nilai rata-rata siswa yaitu 71 dengan jumlah siswa 33 orang. Keterlaksanaan Pendekatan Sains Teknologi Masyarakat pada penelitian ini dalam kategori baik agar bisa mengatasi permasalahan dalam kurangnya penggunaan fasilitas atau media yang ada ketika dalam pembelajaran. Karena terdapat pengaruh positif dan signifikan dari fasilitas belajar untuk menunjang hasil belajar yang baik

\section{DAFTAR PUSTAKA}

Aunurrahman. (2011). Belajar dan Pembelajaran. Bandung: Alfabeta.

Aziz, A. A., Yusof, K. M., \& Yatim, J. M. (2012). Evaluation on The Effectiveness of Learning Outcomes from

Students Perspectives.

Daryanto dan Muhammad Farid. 2013. Konsep Dasar Manaajemen

Pendidikan Nasional. Yogyakarta: Gava Media.

Gudeva, L. K., Dimova, V., Daskalovska, N., \& Trajkova, F. (2012). Designing descriptors of learning outcomes for Higher Education. Procedia - Social and Behavioral Sciences 46, 1306-1311.

Lawanson, et al. (2011). "Provision and Management of School Facilities for the Implementation of UBE Programme". Journal of Educational and Social Research. Vol. 1. (4), 47-55.

Samatowa Usman. (2010). Pembelajaran IPA Di Sekolah Dasar. Jakarta: PT Indeks.

Sugiyono. 2013. Metode Penelitian Pendidikan Pendekatan Kuantitatif, Kualitatif, dan R\&D. Bandung: Alfabeta.

Sanjaya, Wina. (2010). Strategi Pembelajaran Berorientasi Standar Proses

Pendidikan. Jakarta : Prenada Media Group

Trisnayanti, N. K. 2010. Implementasi Sains Teknologi, Masyarakat dan Lingkungan Berbasis Masalah dalam Pembelajaran Fisika untuk Meningkatkan Kualitas Pembelajaran. Jurnal Pendidikan Kerta Mandala. 3(3): 61-72.

Usman samatowo. (2006: 2). Bagaimana Membelajarkan IPA Di SD. Jakarta: Depdiknas Dikti

Widyatiningtyas, R. 2009. Pembentukan Pengetahuan Sains, Teknologi dan Masyarakat dalam Pandangan Pendidikan IPA. EDUCARE: JurnalPendidikan dan Budaya. Melalui http://educare.e-fkipunla.net/ [02/08/11]. 